\title{
TAF3 wt Allele
}

National Cancer Institute

\section{Source}

National Cancer Institute. TAF3 wt Allele. NCI Thesaurus. Code C52604.

Human TAF3 wild-type allele is located in the vicinity of 10p15.1 and is approximately 205

$\mathrm{kb}$ in length. This allele, which encodes transcription initiation factor TFIID subunit 3

protein, is involved in the promotion of transcription. 